\title{
EFEKTIFITAS IMPLEMENTASI AKTIVITAS MENGKOMUNIKASIKAN BERBASIS KEPALA BERNOMOR DALAM MENINGKATKAN DIMENSI PROSES KOGNITIF
}

\author{
Ni Wayan Ririn Trisnayanti*, \\ Jurusan Pendidikan Guru Sekolah dasar, FIP, Universitas Pendidikan Ganesha
}

\begin{abstract}
The purpose of this study is to determine the effectiveness of the implementation of a significant dimension of cognitive processes between students who were taught by the activity of communicating head-based communicating with students who were taught by conventional learning model in third grade students of SD in Buleleng Regency. This research was quasi experimental research with Non Equivalent Posstest Only Control Group Design design. The data were collected by using objective and esay tests. The data were analyzed by using descriptive statistics and inferential statistics. The results of this study showed that the activity of communicating headbased communicating effectively increase the dimension of student cognitive process. It can be seen from the average value of experimental group which was in very high category and the average value of the control group was in hig category. So experiment $=28,5>$ control $=21,05$, and result of hypothesis test by using t-test was obtained $t_{\text {count }}$ bigger than $t_{\text {table }}\left(t_{\text {count }}=3,62>t_{\text {table }}=2,93\right)$
\end{abstract}

\author{
Keywords: \\ Communicating \\ Activities, Numbered \\ Heads, Cognitive Process \\ Dimensions
}

\section{Pendahuluan}

Salah satu upaya yang ditempuh untuk meningkatkan kualitas pendidikan adalah dengan menerapkan Kurikulum 2013 yang disusun dengan dilandasi pemikiran tantangan masa depan, yaitu tantangan abad ke-21 yang ditandai dengan abad ilmu pengetahuan, knowledge-based society dan kompetensi masa depan. Pelaksanaan Kurikulum 2013 adalah suatu proses penerapan ide, konsep dan kebijakan kurikulum dalam suatu aktivitas pembelajaran sehingga peserta didik menguasai seperangkat kompetensi tertentu, sebagai hasil interaksi dengan lingkungan sekitarnya (Izzati, 2015). Pembelajaran dalam kurikulum 2013 menekankan pada proses pembelajaran yang menggunakan kaidah-kaidah pendekatan saintifik di dalam proses pembelajarannya, hal ini didukung oleh (Chen \& She, 2013, p.3) yang menjelaskan bahwa "The National Research Council (1999) specified science reasoning skills as the ability to define a scientific question, plan a way to answer the question, analyze data, and interpret result"

Terkait dengan itu, penerapan aktivitas pembelajaran dalam pendekatan saintifik yang diterapkan secara sempurna dapat menjadi alternatif pembelajaran untuk mendapatkan pembelajaran yang bermakna. Dalam penerapan pendekatan saintifik, proses pembelajaran akan lebih berkesan dan bermakna bagi siswa, jika mengajak siswa untuk memperoleh pengetahuan dan informasi baru secara mandiri tidak bergantung pada informasi searah dari guru (Rahmani, 2016).

Hasil observasi pada tahun 2017 di Sekolah Rintisan Kurikulum 2013 di Kabupaten Buleleng menemukan bahwa inovasi dalam aktivitas pembelajaran yang dilakukan saat ini masih kurang inovatif. Hal ini terlihat dari beberapa aktivitas pembelajaran tematik. Pertama, guru lebih mendominasi kegiatan pembelajaran dan kurang memberikan kesempatan kepada siswa untuk unjuk secara langsung terutama dalam hal mengkomunikasikan suatu materi pembelajaran. Kedua, guru juga belum mampu untuk memfasilitasi perkembangan proses kognitif siswa, hal ini dapat terjadi karena guru belum memahami betul apa itu proses kognitif. Ketiga, guru cenderung menggunakan metode ceramah sehingga pengetahuan siswa tentang sesuatu bersifat verbalis, dengan menggunakan metode ceramah siswa tidak mampu untuk menemukan sendiri konsep-konsep yang dipelajari. Keempat, kurangnya pemahaman guru 
terhadap aktivitas pembelajaran yang inovatif yang bisa di sisipkan dalam proses pembelajaran. Kelima, guru belum memaksimalkan pemanfaatan potensi lingkungan sebagai media dan sumber belajar. Keenam, pembelajaran di kelas masih menekankan pada keterampilan mengerjakan soal dan menyelesaikan soal hanya terpaku pada contoh penyelesaian yang diberikan oleh guru.

Temuan tersebut didukung oleh Noor dan Husna (2017) yang mengemukakan bahwa guru jarang menggunakan model pembelajaran, mereka hanya menggunakan model pembelajaran langsung yaitu guru menuliskan dan menjelaskan materi yang dipelajari, memberikan soal latihan untuk dikerjakan masing-masing siswa kemudian latihan tersebut dikumpul untuk diberi nilai oleh guru. Guru berperan secara dominan sehingga informasi hanya berjalan satu arah dari guru ke siswa, dan siswa tidak berani menyampaikan pendapat dan mengajukan pertanyaan pada saat pembelajaran berlangsung yang menyebabkan kemampuan mengkomunikasikan siswa masih rendah. Yudiastuti,dkk (2014) menyatakan bahwa sebagian besar guru masih menggunakan metode ceramah dalam melaksanakan kegiatan pembelajarannya. Sehingga proses pembelajaran menjadi monoton. Banyak penyebab penggunaan metode ceramah dilakukan di sekolah-yaitu karena kurangnya motivasi guru untuk melaksanakan pembelajaran bermakna.

Para guru di Sekolah Dasar Rintisan Kurikulum 2013 di Kabupaten Buleleng masih berpandangan bahwa mengemas pembelajaran hanya dilihat berdasarkan ketuntasan belajar yang dicapai siswa tanpa memperhatikan proses kognitif yang dicapai oleh siswa. Hal ini dirasa bertentangan dengan paham konstruktivisme yang menyatakan bahwa siswa dalam segala usia secara aktif terlibat dalam proses perolehan informasi dan membangun pengetahuannya sendiri (Jampel dkk, 2015). Berdasarkan hasil observasi dan tes studi pendahuluan yang dilakukan pada kelas III semester genap tahun pelajaran 2016/2017 ditemukan bahwa hasil belajar siswa kelas III di SD Rintisan Kurikulum 2013 di Kabupaten Buleleng tergolong rendah. Hal tersebut terlihat pada pencapaian nilai tes studi pendahuluan siswa masih di bawah KKM yaitu 65. Dari 11 kelas yang tersebar di 7 sekolah terdapat 10 kelas yang mendapatkan nilai rata-rata dibawah 65.

Hasil wawancara dengan guru dan siswa ditemukan bahwa masalah rendahnya kualitas dimensi proses kognitif siswa muncul karena ada beberapa faktor kepribadian yang mendukung untuk belajar seperti kurangnya motivasi, dan ketidakyakinan dengan kemampuan diri. Selain itu, permasalahan yang terjadi dalam pembelajaran juga menyebabkan kurang antuasiasnya siswa ketika pembelajaran berlangsung. Pada saat jam pembelajaran berlangsung siswa kebanyakan tidak berkonsentrasi dalam belajar. Hal ini sesuai dengan hasil observasi saat pembelajaran tematik, dimana cara guru menyampaikan materi pembelajaran terlihat kurang menarik, sehingga terlihat beberapa anak nampak tidak memperhatikan guru yang sedang menjelaskan materi di depan kelas.

Dalam proses pembelajaran guru terlihat lebih berperan aktif dalam menyajikan informasi. Sedangkan siswa cendurung pasif dan kurangnya proses berpikir dari siswa. Hal ini juga sejalan dengan hasil penelitian Tirtasari (2015) yang menyatakan bahwa rendahnya hasil belajar siswa diakibatkan oleh kurang inovatifnya guru dalam mengemas proses pembelajaran. Dari pemaparan tersebut, adapun upaya yang dapat dilakukan untuk mengatasi kelemahan-kelemahan yang dihadapi oleh guru di lapangan, yaitu dengan melaksanakan proses pembelajaran yang bermakna dengan memperhatikan proses kognitifnya dan langsung melibatkan siswa secara aktif atau berpusat pada siswa. Temuan tersebut didukung oleh Widodo (2015) yang mengemukakan bahwa perubahan paradigma pembelajaran, dari berpusat pada guru menjadi strategi pembelajaran yang berpusat pada siswa merupakan upaya untuk mengoptimalkan proses pembelajaran yang menumbuhkan siswa. Temuan tersebut juga didukung oleh Wartini(2014) yang menyatakan pembelajaran yang menuntut siswa yang aktif dalam melakukan keterampilan ilmiah tentunya membuat interaksi siswa dengan guru maupun siswa dengan siswa akan terjalin dengan efektif maka pembelajaran akan menjadi bermakna bagi siswa.

Dengan menggunakan aktivitas pembelajaran seperti itu maka siswa akan lebih mudah memahami suatu konsep yang telah dipelajari, dengan dipahaminya suatu konsep maka siswa akan dengan mudah dapat mengkomunikasikan kembali pelajaran yang mereka pelajari. Hal tersebut sejalan dengan temuan Martunis, dkk (2014) yang menyebutkan melalui komunikasi siswa dapat mengorganisasi dan mengkonsolidasi berpikir matematisnya baik secara lisan maupun tulisan dalam proses pembelajaran. Pada akhirnya komunikasi dapat membawa siswa pada pemahaman yang mendalam tentang konsep yang telah dipelajari.

Guna mereliasasikan hal ini maka dibutuhkan suatu pembelajaran yang bersifat inovatif. Pembelajaran yang dipilih dan sesuai untuk mengatasi masalah yang terjadi adalah aktivitas pembelajaran mengomunikasikan berbasis Kepala Bernomor. Kepala bernomor ini merupakan suatu variasi aktivitas pembelajaran yang mirip dengan model pembelajaran yang biasa disebut dengan model Numbered Head Together. NHT merupakan salah satu jenis model yang dikembangkan oleh Spencer Kagan 
(1992) untuk melibatkan lebih banyak siswa dalam menelaah materi yang tercakup dalam suatu pelajaran dan mengecek pemahaman mereka terhadap isi pelajaran

Aktivitas pembelajaran ini sangat relevan dengan karakteristik tematik SD yang menkankan pada fenomena dan perubahan-perubahan lingkungan sekitar sebagai konteks bagi siswa untuk belajar. Siswa akan dilatih dan dibiasakan untuk saling berbagi (sharing) pengetahuan, pengalaman, tugas dan tanggung jawab, saling membantu dan berlatih berinteraksi-komunikasi sosialisasi. Adapun beberapa kelebihan yang ditawarkan oleh pembelajaran ini yaitu dapat meningkatkan prestasi belajar siswa, mampu memperdalam pemahaman siswa, menyenangkan siswa dalam belajar, mengembangkan rasa ingin tahu siswa, meningkatkan rasa percaya diri siswa, tercipta suasana gembira dalam belajar. Dengan demikian meskipun saat pelajaran menempati jam terakhir pun, siswa tetap antusias dalam belajar.

Berdasarkan hasil penelitian yang pernah dilakukan oleh I Nyoman Krisna Mahendra Hadiputra Tahun 2015 menyatakan di dalam penerapannya siswa yang dibelajarkan dengan model pembelajaran NHT keaktifan siswa meningkat baik dari perhatian, sikap aktif, sikap mengkomunikasikan maupun hasil belajarnya. Pernyataan tersebut juga didukung dengan penelitian yang dilakukan oleh Maheady (2006) yang melihat dampak dari Numbered Head Together adalah model ini efisien dan efektif untuk meningkatkan siswa kemampuan siswa untuk menanggapi dan untuk meningkatkan prestasi. Hal ini juga diperkuat oleh Lince (2016) yang menyatakan Belajar dengan kepala bernomor lebih baik dari pada metode konvensional, dalam menerapkan pembelajaran ini siswa dituntut untuk memiliki pemikiran kreatif matematis yang memainkan peran penting, baik dalam memecahkan masalah maupun untuk menyampaikan gagasan.Penerapan aktivitas pembelajaran yang tepat pada pembelajaran akan lebih menyenangkan dan menarik jika dibantu dengan menyisipkan kegiatan pembelajaran yang menarik seperti Kepala Bernomor.

Kepala bernomor ini akan membantu siswa untuk belajar mengkomunikasikan apa yang mereka ketahui mengenai pembelajaran yang mereka pelajari. Berdasarkan pemaparan tersebut, diketahui bahwa antara aktivitas pembelajaran mengkomunikasikan berbasis Kepala Bernomor dengan pembelajaran konvensional memiliki karakteristik dan teori, yang berbeda. Sehingga jika diterapkan pada siswa maka akan menghasilkan output yang berbeda karena mereka akan mempelajari keterampilan mengkomunikasikan dari apa yang mereka lakukan saat belajar bersama teman-temannya. Sejauh mana efektifitasimplementasiitu pada pembelajaran Tematik dengan mengambil objek penelitian yakni siswa kelas III akan diteliti pada penelitian ini adalah untuk menguji keefektifan implementasi aktifitas mengkomunikasikan berbasis kepala bernomor dalam meningkatkan dimensi proses kognitif siswa. Guru dapat menjadikan hasil penelitian ini sebagai salah satu refrensi dalam meningkatkan aktivitas pembelajaran menjadi lebih menarik, menantang, memotivasi dan menyenangkan dalam pembelajaran tematik di Sekolah Dasar. Hasil penelitian ini mendukung capaian belajar siswa berdasarkan kompetensi dasar yang diharapkan pada siswa kelas III di Sekolah Dasar. Hasil penelitian ini juga memberikan kontribusi terhadap perkembangan proses kognitif siswa dalam pembelajaran tematik.

\section{Metode}

Jenis penelitian yang digunakan adalah quasi eksperiment. Journal ini dibuat dari hasil penelitian semu dengan rancangan penelitian post-test only control group design. Penelitian ini dilaksanakan di SD Rintisan Kurikulum 2013 di Kabupaten Buleleng dengan rentang waktu semester 2 (genap) pada tahun pelajaran 2016/2017. Populasi pada penelitian ini adalah seluruh siswa kelas III di SD Rintisan Kurikulum 2013 di Kabupaten Buleleng tahun pelajaran 2016/2017. Banyak siswa seluruhnya 358 orang yang tersebar dalam 7 Sekolah Dasar yaitu SDN Kampung Baru, SDN 3 Banjar Jawa, SDN 4 Kaliuntu, SDN 4 Banyuasri, SDN 6 Pejarakan, SDN 1 Busungbiu dan SD Laboratorium Undiksha. Total populasi berjumlah 356 orang yang terbagi menjadi 11 kelas. Sampel diambil dengan cara random sampling yang berjumlah 68 orang terbagi menjadi dua kelas.

Data yang ingin diketahui dalam penelitian ini adalah dimensi proses kognitif siswa dalam pembelajaran tematik tema 7 subtema 2 dan 3 . Metode pengumpulan data yang digunakan adalah tes objektif dan tes esay yang berjumlah 25 butir yang terdiri dari 20 butir tes objektif dan 5 butir tes esay yang sudah divalidasi secara konten dan empiric. Secara konten, tes yang digunakan sudah memenuhi unsur kompetensi dasar dengan kalimat yang baik sesuai dengan perkembangan psikologis anak usia kelas III Sekolah Dasar. Sedangkan analisis validasi empiriknya yang ditinjau dari analisis konsistensi internal tes terhadap 25 tes, dan terdapat 2 tes yang diujikan dinyatakan tidak valid. Analisis daya beda butir tes didapatkan 2 butir tes yang berkualifikasi baik, 20 butir yang berkualifikasi cukup baik dan 1 butir soal yang berkualifikasi jelek. Analisis tingkat kesukaran tes didapatkan 6 butir tes berada pada krtiteria sedang dan 17 butir soal berada pada kriteria mudah. Analisis reliabilitas tes menyatakan bahwa reliabilitas tes objektif berada pada kualifikasi tinggi $(0,602)$ sedangkan reliabiltas tes esay berada pada 
kualifikasi tinggi $(0,62)$. Data dimensi proses kognitif siswa pada tema 7 subtema 2 dan 3 diambil dengan memberikan post-test pada siswa setelah selesai menerapkan aktifitas pembelajaran mengkomunikasikan berbasis kepala bernomor dalam pendekatan saintifik dan menerapkan model pembelajaran konvensional.

Hipotesis dalam penelitian ini dianalisis dengan menggunakan uji t. Namun untuk memberikan gambaran terhadap sebaran data penelitian ini menggunakan analisis deskriptif dengan kriteria rata-rata ideal dan standar deviasi ideal seperti pada Tabel 1.

Tabel 1.Kriteria Rata-rata Ideal danStandarDeviasi Ideal

\begin{tabular}{ccc}
\hline RentangSkor & RentangSkor Real & Kategori \\
\hline $\mathrm{Mi}+1,5 \mathrm{SDi} \leq \mathrm{M} \leq \mathrm{Mi}+3,0 \mathrm{SDi}$ & $28,45 \leq \mathrm{M} \leq 37,9$ & SangatTinggi \\
$\mathrm{Mi}+1,5 \mathrm{SDi} \leq \mathrm{M} \leq \mathrm{Mi}+1,5 \mathrm{SDi}$ & $22,15 \leq \mathrm{M} \leq 28,45$ & Tinggi \\
$\mathrm{Mi}-$ 0,5 SDi $\leq \mathrm{M} \leq \mathrm{Mi}+$ 0,5 SDi & $15,85 \leq \mathrm{M} \leq 22,15$ & Sedang \\
$\mathrm{Mi}-1,5 \mathrm{SDi} \leq \mathrm{M} \leq \mathrm{Mi}-0,5 \mathrm{SDi}$ & $9.55 \leq \mathrm{M} \leq 15,85$ & Rendah \\
$\mathrm{Mi}-3,0 \mathrm{SDi} \leq \mathrm{M} \leq \mathrm{Mi}-1,5 \mathrm{SDi}$ & $0,1 \leq \mathrm{M} \leq 9,55$ & SangatRendah \\
\hline
\end{tabular}

\section{Hasil dan Pembahasan}

Penelitian ini menemukan bahwa pada kelompok eksperimen dimensi proses kognitif siswa setelah mengikuti aktivitas pembelajaran mengkomunikasikan berbasis kepala bernomor dalam pendekatan saintifik sebanyak 65,62\% siswa mendapatkan nilai kategori sangat tinggi, siswa yang mendapatkan kategori tinggi sebanyak 25\%, siswa yang mendapatkan kategori sedang sebanyak 6,26\% dan 3,12\% siswa yang mendapatkan kategori rendah.

Hasil berbeda didapatkan pada kelompok kontrol, yang mana pada kelompok kontrol dimensi proses kognitif siswa setelah mengikuti pembelajaran konvensional sebanyak 17,64\% siswa mendapatkan nilai kategori sangat tinggi, siswa yang mendapatkan kategori tinggi sebanyak 52,94\%, siswa yang mendapatkan nilai katerori sedang sebanyak 29,41\%. Lebih detail hasil post-test terhadap 32 orang pada kelompok eksperimendan terhadap 34. ditunjukkan pada Tabel 2

Tabel 2.Hasil Post-Test siswa kelompok eksperimen dan control

\begin{tabular}{cccc}
\hline Rentang Skor Real & Kelompok Eksperimen & Kelompok Kontrol & Kategori \\
\hline $28,45 \leq \mathrm{M} \leq 37,9$ & $65,62 \%$ & $17,64 \%$ & Sangat Baik \\
$22,15 \leq \mathrm{M} \leq 28,45$ & $25 \%$ & $52,94 \%$ & Baik \\
$15,85 \leq \mathrm{M} \leq 22,15$ & $6,26 \%$ & $29,41 \%$ & Cukup \\
$9.55 \leq \mathrm{M} \leq 15,85$ & $3,12 \%$ & $0 \%$ & Kurang \\
$0,1 \leq \mathrm{M} \leq 9,55$ & $0 \%$ & $0 \%$ & Sangat Kurang \\
\hline
\end{tabular}

Berdasarkan kriteria skala lima dan sesuai dengan hasil analisis data bahwa mean dimensi proses kognitif pada kelompok yang dibelajarkan dengan menggunakan aktivitas pembelajaran mengkomunikasikan berbasis kepala bernomor dalam pendekatan saintifik adalah 28,05 (berada pada kategori tinggi atau sangat baik). Sebaliknya mean dimensi proses kognitif pada kelompok yang dibelajarkan dengan menggunakan model pembelajaran konvensional adalah 21,05 (berada pada kategori cukup). Hal itu berarti bahwa nilai rata-rata dimensi proses kognitif siswa kelompok eksperimen lebih tinggi dari pada nilai rata-rata siswa kelompok konvensional. Data rata-rata dan standar deviasi hasil post-test kedua kelompok disajikan pada tabel 3 .

Tabel 3.Rerata dan Standar Deviasi Data Hasil Post-Test Kelompok Eksperimen dan Kontrol

\begin{tabular}{lcc}
\hline Kelompok & Rata-rata (Mean) & Standar Deviasi \\
\hline Eksperimen & 28,05 & 5,47 \\
Kontrol & 21,05 & 4,41 \\
\hline
\end{tabular}


Sebelum dilakukan pengujian hipotesis dengan uji t independent terlebih dahulu dilakukan pengujian terhadap prasyarat yang diperlukan terhadap sebaran data hasil penelitian. Uji prasyarat analisis meliputi dua hal, yaitu (1) uji normalitas distribusi data terhadap keseluruhan unit analisis, dan (2) uji homogenitas varian antar kelompok,

Uji normalitas data dilakukan pada keseluruhan unit analisis yaitu kelompok eksperimen dan kelompok kontrol. Analisis yang digunakan pada pengujian normalitas sebaran data adalah analisis chi kuadrat. Ketentuan normalitas data ditentukan dengan melihat signifikansi hasil analisis. Data berdistribusi normal jika angka signifikansi yang diperoleh kurang dari 0,05 pada taraf signifikansi 5\%. Ringkasan hasil uji normalitas data pada kelompok eksperimen dan kelompok kontrol disajikan pada tabel 4.

Tabel 4.Ringkasan Hasil Uji Normalitas Distribusi Data

\begin{tabular}{llll}
\hline Model Pembelajaran & \multicolumn{3}{c}{ Chi-Kuadrat } \\
\cline { 2 - 4 } & Statistic & Df & Sig \\
\hline Kelompok Eksperimen & 6,552 & 32 & 7,815 \\
Kelompok Kontrol & 5,688 & 34 & 7,815 \\
\hline
\end{tabular}

Berdasarkan tabel 4 dapat dijelaskan bahwa nilai signifikansi berda dibawah 0,05. Hal ini menunjukkan bahwa sebaran data pada kelompok eksperimen berdistribusi normal. Hasil yang hampir sama juga diperoleh pada data kelompok kontrol yang sama memiliki distribusi normal.

Uji homogenitas varians dilakukan berdasarkan data dimensi proses kognitif pada kelompok eksperimen dan kelompok kontrol. Jumlah masing-masing unit analisis adalah 32 dan 34 orang siswa. Uji homogenitas varians antar kelompok menggunakan uji F. data dinyatakan homogeny jika $F_{\text {hitung }}<F_{\text {tabel. }}$ Ringkasan hasil uji homogenitas varians antara kelompok disajikan dalam Tabel 5.

Tabel 5.Ringkasan Hasil Uji Homogenitas Varians dengan Uji F

\begin{tabular}{|c|c|c|c|c|c|c|}
\hline Sampel & Mean & SD & Varians & thitung & ttabel & $\begin{array}{c}\text { Kesimpula } \\
\text { n }\end{array}$ \\
\hline Eksperimen & 28,05 & 5,47 & 29,98 & & & \\
\hline Kontrol & 21,05 & 4,41 & 19,53 & 1,53 & 1,84 & $\begin{array}{c}\text { Fhitung< } \\
\text { Ftabel }\end{array}$ \\
\hline
\end{tabular}

Berdasarkan tabel 5 ringkasan data hasil uji homogenitas varians untuk kedua kelompok model pembelajaran menunjukkan bahwa $F_{\text {hitung }}<F_{\text {tabel. }}$ Ini berarti bahwa varians antara kelompok siswa homogeny.

Hipotesis penelitian yang diuji adalah terdapat perbedaan yang signifikan dimensi proses kognitif siswa yang belajar menggunakan aktifitas pembelajaran mengkomunikasikan berbasis kepala bernomor dalam pendekatan saintifik dan siswa yang belajar menggunakan model pembelajaran konvensional. Untuk menguji hipotesis yang diajukan digunakan uji-t tidak berkolerasi atau $t$-test independent. Tabel 6 menunjukkan bahwa varian homogeny dan jumlah siswa tiap kelas yang sama maka uji-t tidak berkolerasi ini digunakan rumus polled varians. Ringkasan hasil uji-t tidak berkolerasi pada tabel 6 .

Tabel 6.Ringkasan Data Hasil Uji Hipotesis

\begin{tabular}{|c|c|c|c|c|c|c|}
\hline Kelompok & Varian & $\mathrm{N}$ & $\mathrm{db}$ & thitung & ttabel & $\begin{array}{l}\text { Kesimpula } \\
\mathrm{n}\end{array}$ \\
\hline Kelompok Eksperimen & 29,98 & 32 & \multirow[b]{2}{*}{64} & \multirow[b]{2}{*}{5,78} & \multirow[b]{2}{*}{2,39} & \multirow{2}{*}{$\begin{array}{c}t_{\text {hitung }}>t_{\text {tabel }} \\
\text { Ha } \\
\text { diterima }\end{array}$} \\
\hline Kelompok Kontrol & 19,53 & 34 & & & & \\
\hline
\end{tabular}

Berdasarkan hipotesis penelitian yang telah diajukan pada kajian teori kriteria pengujian $\mathrm{H}_{0}$ ditolak jika $t_{\text {hitung }}>t_{\text {tabel }}$ dan $\mathrm{H}_{1}$ diterima, dengan taraf signifikansi $5 \%$ dan didukung oleh perbedaan skor rata-rata yang diperoleh antara kelompok eksperimen yaitu 28,05 yang berada pada kategori sangat tinggi dan kelompok kontrol yaitu 21,05 yang berada pada kategori sedang (cukup) maka hipotesis alternative diterima. Ringkasan data hasil uji hipotesis menunjukkan hal yang sama bahwa $t_{\text {hitung }}>\mathrm{t}_{\text {tabel }}$ sehingga $\mathrm{H}_{0}$ ditolak dan $\mathrm{H}_{1}$ diterima. Dengan demikian dapat diinterpretasikan bahwa terdapat keefektifanimplementasiyang signifikan dimensi proses kognitif yang belajar menggunakan aktivitas pembelajaran mengkomunikasikan berbasis kepala bernomor dalam pendekatan saintifik dan kelompok siswa yang dibelajarkan dengan menggunakan model pembelajaram konvensional pada pelajaran 
Tematik Tema 7 subtema 2 dan 3 siswa kelas III Semester Genap tahun pelajaran 2016/2017 di SD Rintisan Kurikulum 2013 di Kabupaten Buleleng.

\section{Pembahasan}

Hasil penelitian ini menemukan bahwa terdapat perbedaan yang signifikan dimensi proses kognitif siswa yang dibelajarkan dengan aktivitas pembelajaran mengkomunikasikan berbasis kepala bernomor dalam pendekatan saintifik dengan model pembelajaran konvensional. Berdasarkan nilai rata-rata dimensi proses kognitif pada kelompok yang dibelajarkan dengan menggunakan aktivitas pembelajaran mengkomunikasikan berbasis kepala bernomor adalah 28,05 lebih tinggi daripada rata-rata dimensi proses kognitif pada kelompok yang dibelajarkan dengan pembelajaran konvensional adalah 21,05 . Jadi itu berarti bahwa aktivitas pembelajaran mengkomunikasikan berbasis kepala bernomor berpengaruh positif terhadap dimensi proses kognitif siswa kelas III Semester Genap tahun Pelajaran 2016/2017 di SD Rintisan Kurikulum 2013 di Kabupaten Buleleng.

Hasil penelitian ini menunjukkan bahwa pada kelompok siswa yang diberikan pembelajaran aktivitas pembelajaran mengkomunikasikan berbasis kepala bernomor sebanyak sebanyak $65,62 \%$ siswa mendapatkan nilai kategori sangat tinggi, siswa yang mendapatkan kategori tinggi sebanyak 25\%, siswa yang mendapatkan kategori sedang sebanyak 6,26\% dan 3,12\% siswa yang mendapatkan kategori rendah. Hal tersebut dapat terjadi karena siswa benar-benar memahami materi yang telah dipelajari melalui aktivitas mengkomunikasikan berbasis kepala bernomor. Hasil berbeda didapatkan pada kelompok kontrol, yang mana pada kelompok kontrol dimensi proses kognitif siswa setelah mengikuti pembelajaran konvensional sebanyak $17,64 \%$ siswa mendapatkan nilai kategori sangat tinggi, siswa yang mendapatkan kategori tinggi sebanyak $52,94 \%$, siswa yang mendapatkan nilai katerori sedang sebanyak $29,41 \%$.

Hal tersebut juga didukung oleh temuan dari data lapangan yang memperlihatkan bahwa hasil proses kognitif siswa dengan menerapkan aktrivitas pembelajaran mengkomunikasikan berbasis kepala bernomor dalam pendekatan saintifik memiliki kecenderungan sebagian besar skor siswa sangat tinggi yang disebabkan oleh beberapa faktor. Faktor pertama yaitu, guru dalam pembelajaran memposisikan diri sebagai mediator dan fasilitator pada saat siswa menyelesaikan masalah melalui penyampaian pendapat secara langsung yang menjadi fokus pembelajaran mengkomunikasikan berbasis kepala bernomor ini. Siswa diarahkan untuk menyampaikan pendapat yang mereka miliki sehingga siswa aktif untuk mengkomunikasikan pengetahuannya sendiri. Hal ini sesuai dengan pendapat yang disampaikan oleh Elliot (dalam Abimanyu, 2008, p.22) bahwa "pembelajaran akan lebih bermakna dan permanen jika siswa diberikan kesempatan aktif membangun pengetahuannya sendiri". Kedua, siswa dibiasakan diberikan masalah dalam bentuk pertanyaan-pertanyaan yang diberikan oleh guru. Masalah yang diberikan oleh guru akan merangsang perkembangan kemajuan berfikir siswa untuk menyelesaikan masalah yang dihadapi kemudian siswa dapat langsung mengkomunikasikan pemecahan atau solusi dari masalah yang diberikan oleh guru dengan tepat. Sedangkan pada model konvensional guru cenderung memposisikan diri sebagai pusat pembelajaran, terutama saat aktivitas mengkomunikasikan, guru hanya menunjuk salah satu siswa untuk mengkomunikasikan pengetahuan yang mereka miliki saat pembelajaran berlangsung, guru juga kurang memberikan ruang gerak yang bebas bagi siswa untuk berkreasi dan mengembangkan kemampuannya sendiri.

Hasil penelitian ini juga didukung oleh Raresik (2016) yang menyatakan faktor-faktor yang mempengaruhi hasil belajarsecara umum dikelompokkan menjadi faktor intern dan faktor ekstern". Faktor intern yang dimaksud adalah faktor-faktor yang berasal dari dalam diri peserta didik yang meliputi faktor fisiologis (fisik) dan faktor psikologis (kejiwaan). Faktor ekstern yaitu faktor-faktor yang berasal dari luar diri peserta didik yaitu faktor sekolah

Berdasarkan temuan tersebut, aktivitas pembelajaran mengkomunikasikan berbasis kepala bernomor dalam pendekatan saintifik dipandang perlu untuk diterapkan dalam pembelajaran, hal ini dikarenakan aktivitas pembelajaran mengkomunikasikan berbasis kepala bernomor melibatkan peran siswa sebagai problem silver dan listener yang dilakukan secara individual untuk aktif menyelesaikan suatu masalah dan mengkomunikasikan pemecahan masalah tersebut dalam pembelajaran. Di samping itu, ativitas pembelajaran mengkomunikasikan berbasis kepala bernomor juga berorientasi pada kemampuan berfikir konstruktivisme, dimana fokus pembelajaran tergantung masalah yang dipilih sehingga siswa tidak saja mempelajari konsep-konsep yang berhubungan dengan masalah tetapi siswa juga mampu menyampaikan pengetahuan itu dan memberi makna melalui pengalaman nyata. Hal ini dimaksudkan agar tujuan akhir dari proses pembelajaran tersebut dapat tercapai dengan baik dan tepat sasaran.

Hasil penelitian ini juga didukung oleh hasil penelitian Ngadiyanti (2010) yang mengatakan pembelajaran dengan kepala bernomor memberikan kesempatan kepada siswa untuk terlibat secara aktif 
dalam proses berpikir, memberikan ide-ide atau gagasan, serta mempertimbangkan jawaban yang tepat dalam menjawab suatu pertanyaan yang diberikan oleh guru secara kelompok khususnya dalam materi perubahan lingkungan fisik dan pengaruhnya terhadap daratan. Kepala Nernomor digunakan untuk melibatkan lebih banyak siswa dalam menelaah materi yang tercakup dalam suatu pelajaran dan mengecek pemahaman mereka terhadap isi pelajaran tersebut (Trianto, 2007).

Di sisi lain, aktivitas pembelajaran mengkomunikasikan berbasis kepala bernomor dalam pendekatan saintifik yang diterapkan pada kelompok eksperimen dan model pembelajaran konvensional yang diterapkan pada kelompok kontrol dalam penelitian ini menunjukkan pengaruh yang berbeda pada hasil proses kognitif siswa. Hal ini dapat dilihat dari hasil proses kognitif siswa. Secara deskriptif, hasil proses kognitif siswa kelompok eksperimen lebih tinggi mdibandingkan dengan siswa kelompok kontrol. Tinjauan ini didasarkan pada rata-rata skor hasil proses kognitif dan kecenderungan skor hasil proses kognitif. Rata-rata skor hasil proses kognitif siswa kelompok eksperimen adalah 28,05 berada pada kategori sangat baik atau sangat tinggi sedangkan skor hasil proses kognitifsiswa kelompok kontrol adalah 21,05 berada pada kategori baik atau tinggi. Jika skor hasil proses kognitif siswa kelompok eksperimen digambarkan dalam histogram tampak bahwa kurve sebaran data merupakan juling negative yang artinya sebagian besar skor siswa cenderung tinggi. Sedangkan pada kelompok kontrol, jika skor hasil proses kognitif siswa digambarkan dalam grafik histogram tampak bahwa kurve sebaran data merupakan juling positif yang artinya sebagian besar skor siswa cenderung rendah.

Berdasarkan analisis data menggunakan uji-t yang ditunjukkan pada tabel 4.6 diketahui thitung 5,78 dan tabel $(\mathrm{db}=$ dan taraf signifikansi $5 \%)=2,39$. Hasil perhitungan tersebut menunjukkan bahwa thit lebih besar dari $t_{\text {tab }}\left(\mathrm{t}_{\text {hit }}>\mathrm{t}_{\text {tab}}\right)$ sehingga hasil penelitian adalah signifikan. Hal ini berarti, terdapat perbedaan yang signifikan hasil proses kognitif antara siswa yang dibelajarkan dengan aktivitas pembelajaran mengkomunikasikan berbasis kepala bernomor dalam pendekatan saintifik dengan siswa yang dibelajarkan dengan model pembelajaran konvensional. Adanya perbedaan yang signifikan menunjukkan bahwa penerapan aktivitas pembelajaran mengkomunikasikan berbasis kepala bernomor dalam pendekatan saintifik berpengaruh terhadap hasil proses kognitif siswa.

Hasil yang diperoleh oleh penelitian ini juga sejalan dengan hasil penelitian yang dilakukan oleh Hardiputra (2015,p.3) yang menyatakan bahwa dengan menerapkan model pembelajaran kooperatif tipe Numbered Head Together secara efektif pada pembelajaran dapat meningkatkan kemampuan berfikir dan keaktifan siswa dalam pemecahan masalah. Di sisi lain, model pembelajaran kooperatif tipe NHT selain dapat meningkatkan hasil belajar siswa juga dapat merangsang perkembangan kemajuan berfikir dan merangsang perkembangan siswa untuk mengkomunikasikan pemecahan masalah yang dihadapi dengan tepat. Dengan demikian, siswa dituntut untuk bekerja seacra aktif untuk menyelesaikan suatu masalah yang diberikan dan mengkomunikasikan pemecahan masalah tersebut dihadapan teman-temannya sehingga tujuan pembelajaran dapat tercapai dan dimensi proses kognitif siswa menjadi lebih baik. Selain itu, siswa juga dapat mengembangkan kemampuan berpikir dan kemampuan mengkomunikasikan atau berbicara secara optimal yang dilakukan dengan pemberian pertanyaan. Sehingga dengan menerapkan aktivitas pembelajaran mengkomunikasikan berbasis kepala bernomor dalam pendekatan saintifik, materi pelajaran yang diperoleh siswa akan bertahan lebih lama dalam ingatan siswa mengingat pembelajaran dikemas dengan menarik dan menyenangkan.

Hasil penelitian ini menguatkan beberapa hasil penelitian yang ditemukan belakangan ini, diantaranya penelitian yang dilakukan oleh Sastrawan, Wayan.,Gede Sedanayasa., dan Ignatius I Wayan Suwatra (2014, p.1) bahwa model pembelajaran kooperatif tipe numbered head together berpengaruh terhadap hasil belajar IPA siswa. Hasil penelitian lain juga menunjukkan bahwa pembelajaran kooperatif tipe NHT yang diterapkan dalam kegiatan pembelajaran memberikan pengaruh yang signifikan terhadap pencapaian hasil belajar siswa kecara keseluruhan (Yudiastuti, dkk., 2014; Maheady.,dkk,2006; Haydon.,dkk,2010; Lince, 2016).

\section{Kesimpulan}

Penelitian ini menemukan bahwa aktivitas pembelajaran mengkomunikasikan berbasis kepala bernomor dalam pendekatan saintifik berpengaruh positif atau efektif terhadap dimensi proses kognitif siswa kelas III semester genap tahun pelajaran 2016/2017 di SD Rintisan Kurikulum 2013 di Kabupaten Buleleng. Aktivitas pembelajaran mengkomunikasikan berbasis kepala bernomor menunjukkan dimensi proses kognitif siswa lebih baik dari pada model pembelajaran konvensional. Penelitian ini memberikan kontribusi postif terhadap perkembangan keilmuan terutama di bidang pembelajaran Tematik dalam kurikulum 2013. Oleh karena itu disarankan kepada guru-guru yang mengajar tematik hendaknya menyisipkan aktivitas pembelajaran mengkomunikasikan berbasis kepala bernomor sebagai salah satu alternative pembelajaran tematik agar pembelajaran berlangsung lebih efektif dan menyenangkan dan 
juga pada pembuatan soal, dimensi proses kognitif untuk kelas III cukup hanya sampai pada C4 saja, mengingat pada siswa kelas III pemahaman anak masih bersifat kongkret. Penelitian ini juga dapat dijadikan refrensi untuk melakukan penelitian lebih lanjut dengan materi atau pokok bahasan yang berbeda.Tingkatan kelas berbeda dan tambahan variable baru sebagai kreativitas baru.

\section{Daftar Rujukan}

Al-Tabany, T. I. B. 2013. Desain Pengembangan Pembelajaran Tematik. (J. Alfin, Ed.). Jakarta: Prenadamedia Group

Chen, C.-T., \& She, H.-C. 2014. The Effectiveness Of Scientific Inquiry With/Without Integration of Scientific Reasoning. Internasional Journal of Science and Mathematics Education.

Dewi, I. U. 2015. Pengaruh Pendekatan Saintifik Bermuatan Resolusi Konflik Terhadap Sikap Sosial dan Hasil Belajar IPS Siswa Kelas V SD Gugus KOLOnel I Gusti Ngurah Rai,Denpasar Utara. Universitas Pendidikan Ganesha.

Hardiputra, K. M. 2015. Pengaruh Implementasi Pendekatan Saintifik Berbasis Model Pembelajaran Kooperatif Tipe Numbered Head Together (NHT) Terhadap Keaktifan Dan Hasil Belajar IPS Siswa Kelas V SD Gugus Dewi Sartika Denpasar. Universitas Pendidikan Ganesha.

Haydon, T., Maheady, L., \& Hunter, W. 2010. Effects of Numbered Heads Together on the Daily Quiz Scores and On-Task Behavior of Students with Disabilities. J Behav Educ.

Indraloka, P. 2015. Studi Tentang Pengembangan Rancangan Pelaksanaan Pembelajaran Tema Ekosistem Pada siswa Kelas V SD Di Sekolah Rintisan Kurikulum 2013 Kabupaten Buleleng. Universitas Pendidikan Ganesha.

Izzati, R. S. 2015. Implementasi Kurikulum 2013 Bagi Peserta Didik Berkebutuhan Khusus Disekolah Dasar Inklusif.Jurnal Pendidikan Khusus.

Jampel, N., Parmiti, D. P., Widiana, W., \& Jayanta, N. L. (n.d.). Model Pembelajaran Kooperatif Tipe Numbered Head Together berorientasi NOS dalam pembelajaran IPA di Sekolah Dasar.

Kumartha, F., Putra, M., \& Sujana, W. 2013. Pengaruh Pendekatan Pembelajaran Bermakna Bernuansa Lingkungan Alam Terhadap Hasil Belajar IPS Siswa Kelas IV SD Gugus 4 Selemadeg Timur Tabanan.

Lince, R. 2016. Creative Thinking Ability to Increase Student Mathematical of Junior High School by Applying Models Numbered Heads Together. Journal of Education and Practice, 7.

Maheady, L., D, P., Pendl, J. M., Gregory, Harper, F., \& Mallete, B. 2006. The Effect of Numbered Heads Together with and Without an Incentive Package on the Science Test Performance of a Diverse Group of Sixth Graders. Behavioral Education, 15.

Martunis, Ikhsan, M., \& Rizal, S. 2014. Meningkatkan Kemampuan Pemahaman dan Komunikasi Matematis Siswa Sekolah Menengah Atas melalui Model Pembelajaran Generatif. Jurnal Didaktik Matematika, 1.

Ngadiyanti, S. 2010. Meningkatkan Hasil Belajar IPA Melalui Metode Numbered Head Together Pada Siswa Kelas IV SD Negeri 01 Nangsri Kecamatan Kebakkramat Kabupaten Karanganyar Tahun Pelajaran 2009/2010.Universitas Muhammadiyah Surakarta.

Noor, A. J., \& Husna, R. (n.d.). Meningkatkan Kemampuan Komunikasi Matematis Siswa Menggunakan Model Pembelajaran Kooperatif Tipe Student Teams Achiviement Division (STAD). Pendidikan Matematika FKIP Universitas Lambung Mangkurat.

Raresik, A., Dibia, K., \& Widiana, W. 2016. Analisis Faktor-faktor yang Mempengaruhi Hasil Belajar Bahasa Indonesia Pada Siswa Kelas V SD Gugus VI. E-Journal PGSD Universitas Pendidikan Ganesha, 4.

Sastrawan, W., Sedanayasa, G., \& Suwatra, W. 2014. Pengaruh Model Pembelajaran Kooperatif Tipe Numbered Head Together (NHT) Dengan Berbantuan Media Software Pembelajaran Terhadap Hasil Belajar IPA Siswa Kelas V SD Gugus III DEsa Bengkel Kecamatan Busungbiu. Jurnal Mimbar PGSD Universitas Pendidikan Ganesha, 2.

Sujareni, W. 2014. Metodologi Penelitian. Yogyakarta: Pustaka Baru Press.

Susanto, A. 2013. Teori Belajar dan Pembelajaran di Sekolah Dasar. Jakarta: Kencana Prenamedia Group. 
Tirtasari, L., Sudhita, R., \& Rati, W. 2015. Penerapan Pendekatan Contextual Teaching And Learning Untuk Meningkatkan Hasil Belajar IPA Pada Siswa Kelas V. E-Journal PGSD Universitas Pendidikan Ganesha, 3.

Wartini, A. K. M., Lasmawan, W., \& Marhaeni. 2014. Pengaruh Implementasi Pendekatan Saintifik Terhadap Sikap Soaial Dan Hasil Belajar Pkn Di Kelas VI SD Jembatan Budaya Kuta..E-Journal Program Pascasarjana Universitas Pendidikan Ganesha, 4.

Widodo, G., \& Joko. 2015. Pengembangan Dan Implementasi Perangkat Pembelajaran Berbasis Proyek.. Invotec, 11.

Yudiastuti, A. K., Wiarta, W., \&Ardana, K. 2014. Pengaruh Model PembelajaranTipe Numbered Heads Tohether (NHT) BErbantuan Benda Kongkret Terhadap Hasil Belajar Matematik Siswa Kelas V Gugus 1 Dalung Kecamatan Kuta Utara. Jurnal Mimbar PGSD Universitas Pendidikan Ganesha, 2. 